\title{
Pengembangan Modul Pembelajaran Matematika Materi Pecahan Kelas V Sekolah Dasar
}

\author{
Yuli Maghfiroh*, Agustina Tyas Asri Hardini \\ Universitas Kristen Satya Wacana Salatiga, Indonesia \\ *email:292017135@student.uksw.edu
}

\begin{abstract}
This research is motivated by students who have difficulty understanding Mathematics material, especially fractions and the absence of books that can help students understand Mathematics learning material independently. The purpose of this study was to develop a mathematics learning module for fraction material to improve learning outcomes for fifth grade elementary school students. This research is in the form of research and development using the ADDIE model, namely analysis, design, development, implementation, and evaluation. The subjects of this study were fifth grade elementary school students. This research only stopped at the validation test and did not practice using the media in the field. The research instrument is in the form of an expert assessment rubric which consists of an assessment rubric for material experts and media experts. The results of the validation test by material experts conducted by two material experts obtained an average percentage of $76.75 \%$ with the high category. Meanwhile, the results of the validation test by media experts conducted by two media experts obtained an average percentage of $80.73 \%$ with a very high category. Thus the mathematics learning module of fraction material that has been developed is suitable for learning fractions, especially the multiplication and division of fractions and decimals for grade 5 elementary school students.
\end{abstract}

Keywords: module; Mathematics; fraction; primary school

\begin{abstract}
ABSTRAK
Penelitian ini dilatar belakangi oleh siswa yang kesulitan dalam memahami materi Matematika khususnya pecahan dan belum adanya buku yang dapat membantu siswa dalam memahami materi pembelajaran Matematika secara mandiri. Tujuan dari penelitian ini adalah mengembangkan modul pembelajaran Matematika materi pecahan untuk meningkatkan hasil belajar siswa kelas V SD. Penelitian ini berupa penelitian dan pengembangan menggunakan model ADDIE yaitu analysis, design, development, implementation, dan evaluation. Subjek penelitian ini adalah siswa kelas 5 sekolah dasar. Penelitian ini hanya berhenti pada uji validasi dan tidak melakukan praktek peggunaan media di lapangan. Instrumen penelitian ini berupa rubrik penilaian ahli yang terdiri dari rubrik penilaian ahli materi dan ahli media. Hasil uji validasi oleh ahli materi yang dilakukan oleh dua ahli materi mendapatkan persentase rata-rata sebesar 76,75\% dengan kategori tinggi. Sedangkan hasil uji validasi oleh ahli media yang dilakukan oleh dua ahli media mendapatkan persentase rata-rata sebesar 80,73\% dengan kategori sangat tinggi. Dengan demikian modul pembelajaran Matematika materi pecahan yang telah dikembangkan layak digunakan untuk pembelajaran pecahan khususnya perkalian dan pembagian pecahan dan desimal pada siswa kelas 5 sekolah dasar.
\end{abstract}

Kata Kunci: modul; Matematika; pecahan; sekolah dasar

Submitted Apr 01, 2021 | Revised Apr 17, 2021 | Accepted Apr 21, 2021

\section{Pendahuluan}

Pendidikan dasar merupakan fondasi awal dan juga merupakan ujung tombak dunia pendidikan. Melihat posisinya sebagai fondasi dan ujung tombak dalam dunia pendidikan, maka keberhasilan dalam penyelenggaraan pendidikan pada tingkat dasar akan mempengaruhi keberhasilan siswa dalam menempuh pendidikan ditingkat menengah dan juga sampai pada tingkat perguruan tinggi. Salah satu faktor yang mempengaruhi keberhasilan dari pelaksanaan penyelenggaraan sekolah dasar adalah pelaksanaan proses pembelajaran (Soleh, 2009; Amran, 2015; Falah, 2015).

Pembelajaran adalah suatu kegiatan membelajarkan siswa yang bertujuan agar siswa dapat mengetahui segala sesuatu yang belum diketahuinya dan agar terjadi perubahan tingkah laku kearah yang positif (Kurniawati, 2019). Menurut Kurniati (2016) pembelajaran dikatakan efektif dengan ditandai dengan adanya proses belajar oleh diri siswa, adanya wawasan berpikir yang beragam 
sehingga siswa dapat mempelajari berbagai konsep dan mampu mengkaitkannya dengan kehidupan nyata. Dalam kegiatan pembelajaran secaara tidak langsung akan terjadi adanya proses interaksi yang dilakukan antara siswa, siswa dengan guru, dan juga siswa dengan bahan ajar. Menurut Lestari (2013) dalam Nurdyansyah (2018) Bahan ajar adalah seperangkat materi pelajaran yang mengacu pada kurikulum yang digunakan dalam rangka mencapai standar kompetensi dan kompetensi dasar yang telah ditentukan.

Pembelajaran yang dilakukan siswa di sekolah dasar salah satunya adalah Matematika. Menurut Novalia dan Noer (2019) Matematika merupakan ilmu yang mempunyai peran penting dalam berbagai disiplin ilmu. Salah satu materi pembelajaran Matematika yang diajarkan di sekolah dasar adalah pecahan. Menurut Ilahiyah, dkk (2019) pecahan diartikan sebagai bagian dari sesuatu yang utuh. Menurut Kristanto (2016:3), istilah pecahan dapat digunakan untuk merujuk suatu bilangan yang ditulis dalam bentuk $\frac{a}{b}$ dan angka $\frac{a}{b}$ dimana b tidak sama dengan 0 . Salah satu sub materi dari pecahan adalah perkalian dan pembagian pecahan dan desimal. Menurut Aisyah (2012), perkalian pecahan adalah perkalian pembilang dengan pembilang serta penyebut dengan penyebut, perkalian pecahan desimal seperti perkalian bilangan bulat, sedangkan pembagian bilangan pecahan artinya mengalikan bilangan pertama dengan kebalikan bilangan pecahan kedua.

Berdasarkan wawancara dengan wali kelas V SD Negeri 02 Kaliwenang, dalam pembelajaran pecahan khususnya materi perkalian dan pembagian pecahan dan desimal terdapat beberapa permasalahan yang dialami siswa. Siswa mengalami kesulitan dalam memahami konsep pada pecahan dan desimal dikarenakan sifatnya yang abstrak. Buku yang ada juga belum menyajikan gambar pecahan yang diaplikasikan dalam kehidupan sehari-hari. Selain itu ketika siswa dihadapkan dalam soal cerita Matematika, maka siswa akan mengalami kebingungan dan kesulitan. Hal ini sejalan dengan Habibi (2014) bahwa pada siswa sejak berada di tingkat sekolah dasar mengalami kesulitan memahami konsep Matematika, pada jenjang yang lebih tinggi siswa juga akan mengalami kesulitan memahami konsep Matematika yang berakibat pada pencapaian hasil pembelajaran yang rendah. Siswa akan selalu menganggap bahwa Matematika sulit dan menakutkan. Selain dari siswanya, dari pihak guru terkadang dalam menyampaian materi kurang dapat dimengerti oleh siswa (Syahrir \& Susilawati, 2015). Berdasarkan studi pustaka yang telah dilakukan juga ditemukan permasalahan yaitu buku yang digunakan dalam pembelajaran Matematika materi pecahan belum dapat membantu siswa dalam memahami materi pembelajaran secara mandiri. Padahal dalam penyelenggaraan pembelajaran jarak jauh seperti sekarang, diperlukan adanya bahan ajar yang dapat menjadi tutor bagi siswa dalam membantunya memahami materi pembelajaran secara mandiri.

Berdasarkan permasalahan tersebut maka dibutuhkan bahan ajar yang dapat mengatasi berbagai permasalahan yang ada. Salah satu bahan ajar selain buku yang bisa digunakan untuk mendukung keberhasilan pembelajaran adalah modul. Modul menurut Meyer (1978) dalam Lasmiyati dan Hatta (2014) adalah "a modul is relatively short self-contained independent unit of instructional designed to achieve a limited set of specific and well-defined educational objectives. It usually has a tangible format as a set or kit of coordinated and highly produced materials involving a variety of media. A module may or may not be designed for individual selfpaced learning and may employ a variety of teaching techniques". Menurut Prastowo (2011) dalam Tjiptiany, dkk (2016) tujuan dari pembelajaran menggunakan modul yaitu: (a) supaya siswa dapat belajar dengan mandiri atau seminimal mungkin dengan bantuan guru (b) guru tidak mendominasi dan otoriter dalam kegiatan pembelajaran, (3) melatih siswa untuk jujur, (4) mengakomodasi berbagai tingkat dan kecepatan siswa dalam belajar, dan (5) siswa dapat mengukur tingkat penguasaan materinya sendiri. Pembelajaran dengan menggunakan modul dapat memberikan kesempatan kepada siswa yang memiliki kecepatan tinggi dalam belajar untuk dapat lebih cepat menyelesaikan satu kompetensi dasar daripada siswa lain, dengan adanya modul ini akan memudahkan guru mengajar dan memudahkan siswa untuk memahami materi pembelajaran. 
Pada penelitian yang dilakukan oleh Nasution (2016), diperoleh temuan bahwa kemampuan pemecahan masalah matematik siswa mengalami peningkatan, hal ini dapat dilihat dari persentase ketuntasan klasikal siswa pada ujicoba I dan ujicoba II. Dapat disimpulkan dengan penggunaan modul Matematika berbasis masalah, dapat meningkatkan kemampuan siswa dalam memecahan masalah Matematika. Penelitian yang telah dilakukan oleh Wahyuningtyas (2019), diperoleh temuan bahwa validasi modul yang dikembangkan sebesar $96,73 \%$ dan ketercapaian validasi materi pada modul sebesar $76,46 \%$, dan dapat dikatakan bahwa modul yang dikembangkan.

Berdasarkan penjelasan di atas, dibutuhkan media atau bahan ajar yang digunakan dalam pembelajaran yang mampu memberikan gambaran kontekstual terkait materi bilangan pecahan, untuk dapat mempermudah siswa dalam memahami konsep dari pecahan. Agar dapat mengatasi permasalahan yang ada, maka akan dikembangkan suatu produk penelitian yaitu modul pembelajaran Matematika materi pecahan khususnya materi perkalian dan pembagian pecahan dan desimal. Modul ini memiliki kelebihan yaitu siswa akan lebih mudah dalam memahami konsep dan materi pembelajaran pecahan secara mandiri.

Berdasarkan uraian di atas, penelitian ini mempunyai tujuan yaitu mengembangkan modul pembelajaran Matematika materi pecahan untuk meningkatkan hasil belajar siswa kelas V SD. Modul yang dikembangkan bermanfaat bagi guru untuk dapat membantu dalam melaksanakan pembelajaran kurikulum 2013 dan memberikan kemudahan belajar. Modul ini dapat membantu siswa dalam meningkatkan minat dan ketertarikan siswa untuk belajar, serta memberikan kesempatan kepada siswa untuk dapat mempelajari materi secara mandiri.

\section{Metode Penelitian}

Penelitian ini menggunakan jenis penelitian pengembangan (Research And Development/ R\&D). Memilih jenis penelitian R\&D dikarenakan akan mengembangkan modul pembelajaran Matematika. Penelitian pengembangan ini dilaksanakan dengan model pengembangan ADDIE (Analysis, Design, Development, Implementation, \& Evaluation). Menurut Sezer dalam Rayanto \& Sugiyanti (2020), model ADDIE merupakan suatu pendekatan yang menekankan suatu analisa bagaimana setiap komponen yang dimiliki saling berinteraksi satu lainnya dengan berkoordinasi sesuai fase yang ada.

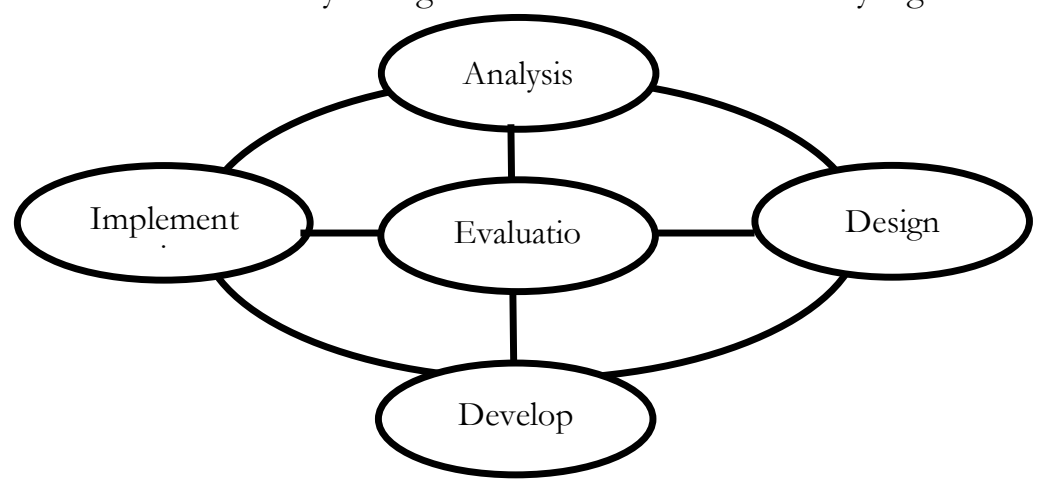

Gambar 1. Model Pengembangan ADDIE

Instrumen penilaian yang digunakan dalam penelitian ini berupa rubrik penilaian ahli. Rubrik penilaian ahli tersebut nantinya akan diberikan kepada validator ahli. Jenis data yaitu data kualitatif yang diperoleh dari rubrik penilaian ahli pada uji validasi ahli materi dan ahli media. Pengisian angket ahli materi dan ahli media yang dilakukan oleh 3 orang ahli yaitu 2 ahli dari dosen pendidikan guru sekolah dasar dan 1 ahli dari dosen pendidikan matematika. Hasil yang didapatkan berupa kritik dan saran perbaikan terhadap modul pembelajaran Matematika materi pecahan. Data yang telah diperoleh dari uji validasi ahli kemudian dilakukan analisis untuk menjawab apakah modul pembelajaran Matematika 
materi pecahan yang dikembangkan sudah dikatakan layak untuk digunakan. Skor yang dipeoleh dari uji validasi ahli, dipersentasekan dalam rumus berikut ini:

Keterangan :

$$
\mathrm{AP}=\frac{\text { Skor Aktual }}{\text { Skor Ideal }} \times 100 \%
$$

AP : Angka Persentase

Skor Aktual : Skor yang diberikan oleh validator ahli

Skor Ideal : Skor maksimal hasil kali jumlah item dari masing-masing item.

Angka yang diperoleh dan sudah dipersentasekan kemudian dikelompokkan kedalam kategori berikut:

Tabel 1. Kategori Uji Validasi

\begin{tabular}{cc}
\hline Interval & Kategori \\
\hline $81-100 \%$ & Sangat tinggi \\
$61-80 \%$ & Tinggi \\
$41-60 \%$ & Cukup \\
$21-40 \%$ & Rendah \\
$1-20 \%$ & Sangat rendah \\
\hline
\end{tabular}

Hasil dari uji validasi ahli materi dalam modul pembelajaran Matematika materi pecahan dapat dikatakan layak untuk diujicobakan apabila persentase minimal mencapai kategori tinggi yaitu $\geq 61 \%$ (Mawardi, 2014:113).

\section{Hasil dan Pembahasan}

Penelitian ini hanya berhenti pada tahap pengembangan (development) yaitu sampai pada uji validasi. Uji validasi dilakukan oleh ahli materi dan ahli media. Dalam pengembangan modul pembelajaran Matematika materi pecahan untuk meningkatkan hasil belajar siswa kelas 5 SD menggunakan model ADDIE yaitu Analysis, Design, Development, Implementation, \& Evaluation.

1. Analysis

Hasil studi pendahuluan yang dilakukan melalui kegiatan wawancara dengan guru kelas V SDN 02 Kaliwenang berkaitan dengan proses kegiatan pembelajaran dan ketersediaannya sumber belajar yang digunakan dalam proses pembelajaran. Dari wawancara didapatkan hasil pada pembelajaran Matematika khususnya materi perkalian dan pembagian pecahan dan desimal, siswa mengalami kesulitan dalam memahami konsep pada pecahan dikarenakan sifatnya yang abstrak. Buku yang ada juga belum menyajikan gambar pecahan yang diaplikasikan dalam kegiatan sehari-hari. Selain itu ketika siswa dihadapkan dalam soal cerita Matematika, maka siswa akan mengalami kebingungan dan kesulitan. Berdasarkan hasil survey melalui jurnal, buku, dan sumber-sumber lain yang relevan. Ditemukan permasalahan yaitu buku yang digunakan dalam pembelajaran Matematika materi pecahan belum dapat membantu siswa dalam memahami materi pembelajaran secara mandiri. Dalam keadaan pendidikan sekarang ini yang dilakukan dengan pembelajaran jarak jauh, dimana dalam pembelajaran ini menuntut siswa untuk dapat belajar secara mandiri.

2. Design

Dilakukan penyusunan draf produk awal sebagai bentuk tanggapan hasil studi pendahuluan. Langkah awal yang dilakukan adalah dengan menyusun draf atau blueprint modul pembelajaran Matematika mencakup:

a) Blueprint modul

Kompetensi dasar yang digunakan untuk mengembangkan modul pembelajaran Matematika adalah materi Matematika kelas $\mathrm{V}$ dengan kompetensi dasar yaitu:

3.2 Menjelaskan dan melakukan perkalian dan pembagian pecahan dan desimal

4.2 Menyelesaikan masalah yang berkaitan dengan perkalian dan pembagian pecahan dan desimal

b) Outline 
Produk modul pembelajaran Matematika materi pecahan memuat tiga komponen atau bagian yakni: komponen pendahuluan, komponen isi, dan komponen penutup.

c) Sistematika modul.

Sistematika modul pembelajaran Matematika materi pecahan meliputi: (1) Komponen pendahuluan berisi halaman sampul, identitas kepemilikan, kata pengantar, daftar isi, petunjuk penggunaan modul, tujuan pembelajaran modul, dan pengantar modul; (2) Komponen isi unit yaitu peta kompetensi, uraian materi, latihan dan tugas mandiri, rangkuman, evaluasi, dan uji kompetensi; (3) Komponen penutup berisi daftar pustaka, biografi penulis, serta kunci jawaban.

3. Development

Berikut adalah hasil produk pengembangan modul pembelajaran Matematika materi pecahan:

Tabel 2. Spesifikasi produk

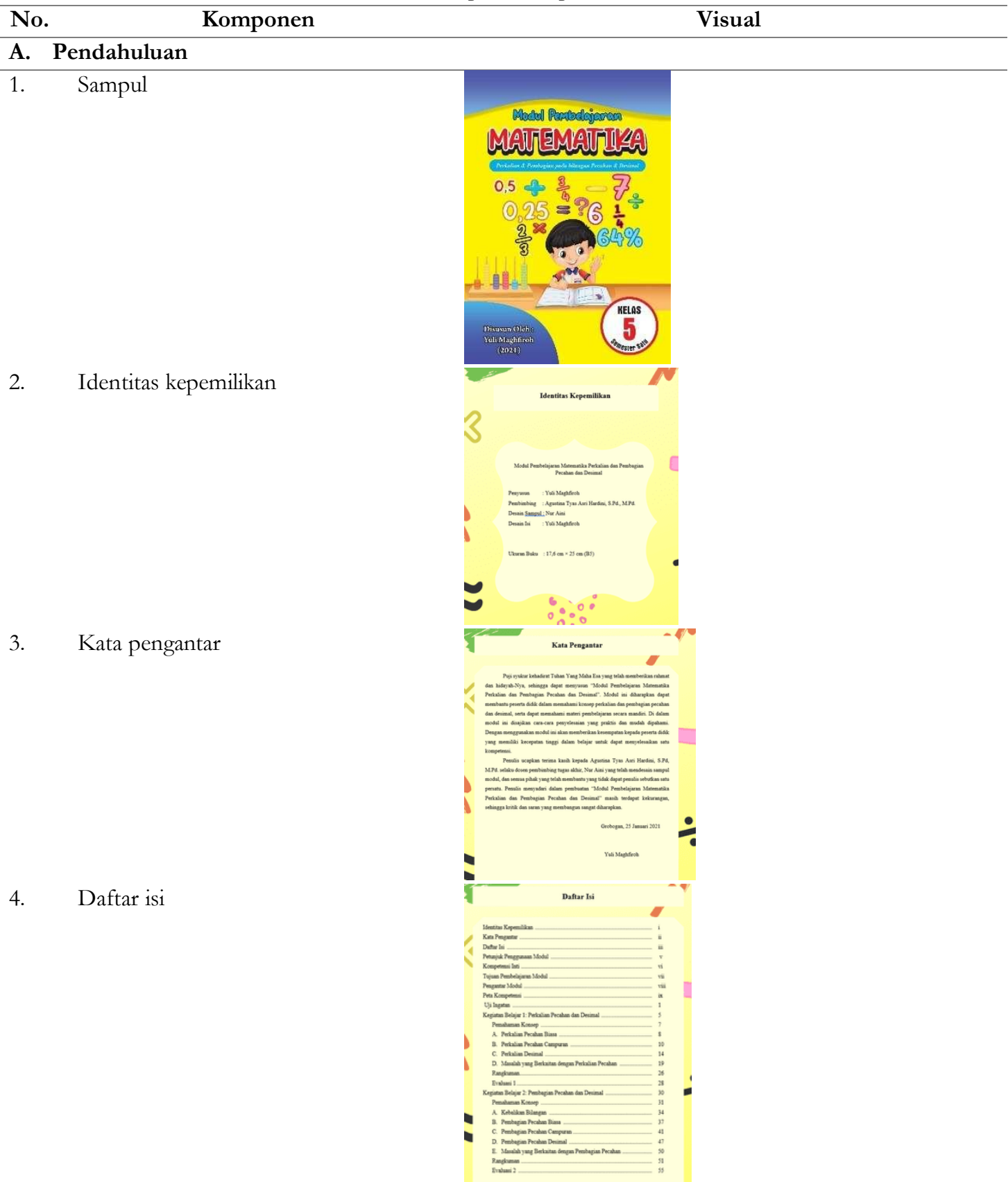


5. Petunjuk penggunaan modul

6. Tujuan pembelajaran modul

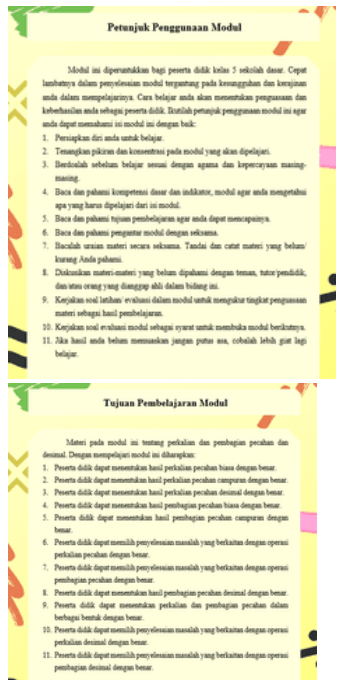

7. Pengantar modul

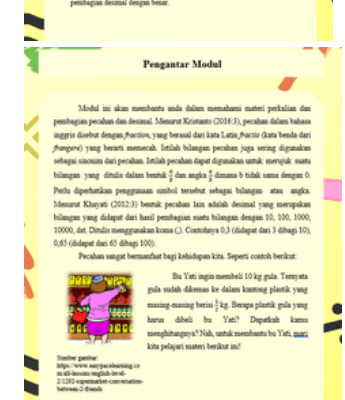

B. Isi

8. Peta kompetensi

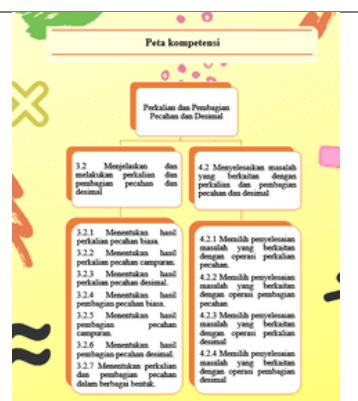

9. Uraian materi

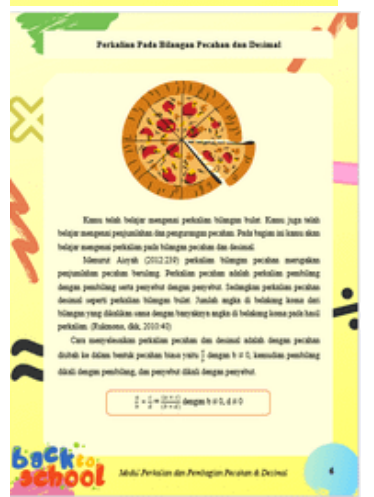

10. Latihan

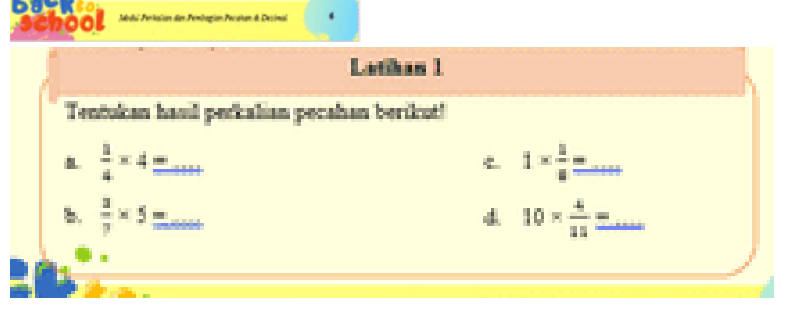


11. Tugas mandiri

12. Rangkuman

13. Evaluasi

14. Uji kompetensi

\section{Penutup}

15. Daftar Pustaka
Tegac Mandivi 1

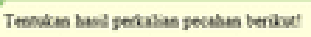

1. $3 \times \frac{4}{3}=$

2. $3 \times 5=$

3. $\frac{1}{3} \times \frac{4}{2}=$

4. $\div \times \frac{2}{3}=$

5. $\frac{1}{3} \times \frac{1}{10}=$

Rasqkeman

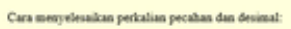

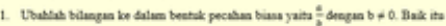

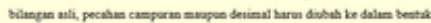

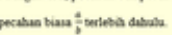

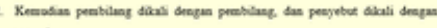
peapetat

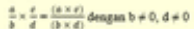

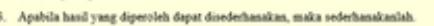

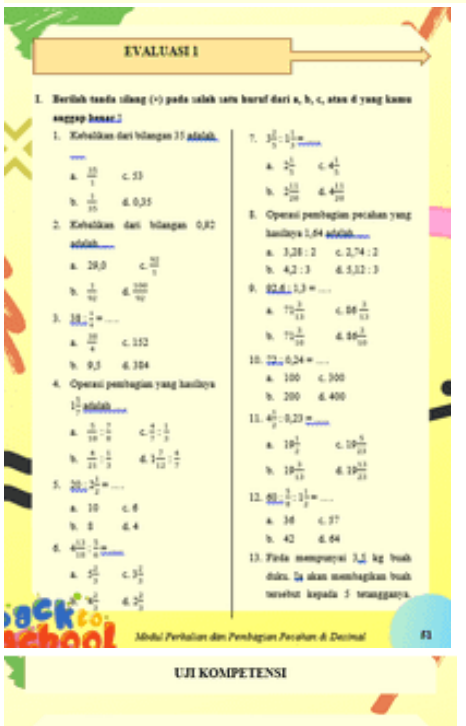

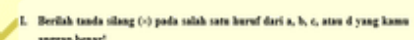

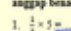

$\begin{array}{llll}2 & \frac{1}{5} & 2 & 24 \\ 0 & 15 & 43\end{array}$

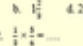

: 21

a. $\frac{1}{14} 41 \frac{1}{4}$

x $1 \times 10$

3
2

b. I 4 $\frac{11}{12}$

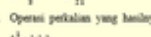

2.

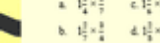

2. $1 \times 4=$

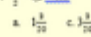

b. $2 \frac{11}{31} 4+\frac{1}{10}$

a.

4. 4 is

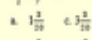

b. $2 \frac{1}{10} 44^{3}$

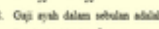

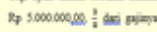

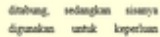

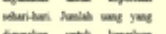

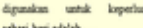

Bes $187 y 00000$

i. $8 p 2500000000$

e R p 1.123000000

Rp 230000000

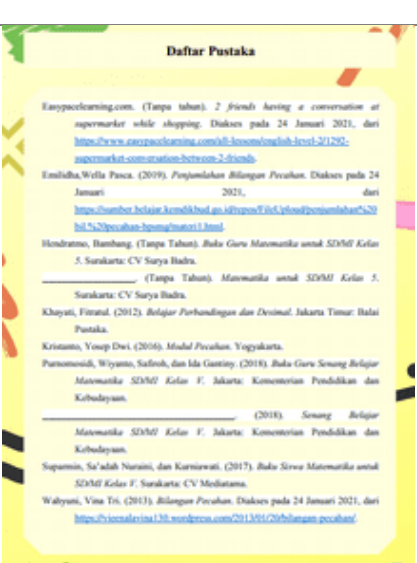


16. Biografi Penulis

17. Kunci Jawaban
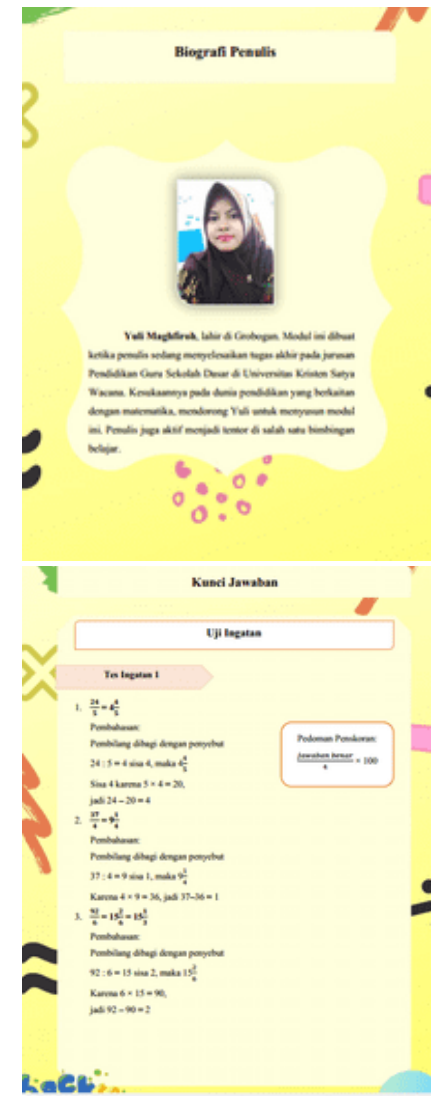

Penelitian pengembangan ini mengembangkan modul pembelajaran Matematika materi pecahan. Pembahasan tingkat validitas modul pembelajaran Matematika materi pecahan dengan skor sebagai berikut:

Tabel 3. Hasil Uji Validitas Ahli

\begin{tabular}{ccccc}
\hline Validator & Skor Ideal & Skor Aktual & AP & Kategori \\
\hline Ahli Materi 1 & 84 & 71 & $84,5 \%$ & Sangat Tinggi \\
Ahli Materi 2 & 84 & 58 & $69 \%$ & Tinggi \\
Ahli Media 1 & 96 & 66 & $68,75 \%$ & Tinggi \\
Ahli Media 2 & 96 & 89 & $92,7 \%$ & Sangat Tinggi
\end{tabular}

Pada ahli materi yang pertama mendapat skor 71 dari 84 dan persentase $84,5 \%$ dengan kategori sangat tinggi. Kemudian dari ahli materi yang kedua mendapatkan skor 58 dari 84 dan persentase $69 \%$ dengan kategori tinggi. Sehingga dalam validasi uji ahli materi mendapatkan persentase rata-rata sebesar 76,75\% dengan kategori tinggi. Sedangkan dari ahli media yang pertama mendapatkan skor 66 dari 96 dan persentase 68,75\% dengan kategori tinggi. Kemudian dari ahli media yang kedua mendapatkan skor 89 dari 96 dan persentase 92,7\% dengan kategori sangat tinggi sehingga dalam validasi uji ahli media mendapatkan persentase rata-rata sebesar 80,73\% dengan kategori sangat tinggi. Hasil kategori tersebut dapat dinyatakan bahwa modul pembelajaran Matematika materi pecahan layak digunakan setelah dilakukan perbaikan sesuai dengan saran ahli materi dan media.

Hasil uji validasi ahli pada pengembangan modul pembelajaran Matematika materi pecahan untuk meningkatkan hasil belajar siswa kelas 5 SD, masuk dalam kategori tinggi dan menurut ahli materi dan media modul pembelajaran Matematika materi pecahan layak untuk digunakan untuk kegiatan pembelajaran. Pernyataan tersebut di dukung oleh hasil penelitian pengambangan yang dilakukan Syahrir dan Susilawati pada tahun 2015, dengan penelitian yang berjudul "Pengembangan Modul Pembelajaran Matematika Siswa SMP”. Diperoleh bahwa produk pengembangan yang berupa modul pembelajaran Matematika untuk siswa SMP layak untuk digunakan. Hal tersebut ditunjukkan dari 
didapatkannya skor rata-rata $82,73 \%$ yang merupakan hasil validasi dari ahli Matematika yang berarti sangat layak, kemudian diperoleh skor rata-rata $92,85 \%$ pada validasi praktisi dengan katagori sangat layak, dan diperoleh skor rata-rata $80,89 \%$ dengan kategori sangat layak pada ujicoba terbatas yang dilakukan pada siswa MTs. Hidayatullah Mataram.

\section{Kesimpulan}

Pengembangan dari modul pembelajaran Matematika materi pecahan dengan menggunakan penelitian $R \& D$, dengan menggunakan model pengembangan ADDIE telah berhasil dikembangkan. Hasil uji validasi ahli materi mendapatkan persentase rata-rata sebesar $76,75 \%$ dengan kategori tinggi. Sedangkan pada ahli media mendapatkan persentase rata-rata sebesar $80,73 \%$ dengan kategori sangat tinggi. Sehingga modul pembelajaran Matematika materi pecahan yang telah dikembangkan layak digunakan untuk pembelajaran pecahan khususnya perkalian dan pembagian pecahan dan desimal pada siswa kelas 5 sekolah dasar.

\section{Ucapan Terima Kasih}

Peneliti bersyukur kepada Allah SWT yang telah memberikan kelancaran dan kemudahan dalam membuat serta menyelesaikan artikel ini. Tak lupa berterima kasih kepada Bapak Ngudi Utomo dan Ibu Muji Rahmini yang telah memberikan semangat dan dukungannya. Terima kasih kepada dosen pembimbing, Ibu Agustina Tyas Asri Hardini, S.Pd., M.Pd. yang telah meluangkan waktu untuk memberikan bimbingan dan juga arahan yang sangat berguna untuk dapat menyelesaikan artikel ini. Terima kasih kepada teman-teman RS17E dan juga para sahabat yang telah memotivasi, memberikan semangat dan dukungannya.

\section{Daftar Pustaka}

Aisyah, Nur. (2012). Sekali Baca Langsung Ingat Semua Pelajaran Kelas 5 SD/ MI. Jakarta: Kunci Aksara.

Amran, A. (2015). Faktor Penentu Keberhasilan Pengelolaan Satuan Pendidikan. Manajer Pendidikan, $9(2)$.

Falah, A. (2015). Studi Analisis Aspek-Aspek Keberhasilan Pembelajaran Pendidikan Agama Islam di SDN 01 Karangmalang Gebog Kudus. ELEMENTARY: Islamic Teacher Journal, 3(1).

Habibi, M. (2012). Pengembangan Modul Pecahan Berbasis Konstruktivisme Dengan Sisipan Karikatur Untuk Kelas IV Sekolah Dasar. In Prosiding Seminar Nasional Pendidikan MatematikaUNINUS (Vol. 2).

Ilahiyah, N., Yandari, I. A. V., \& Pamungkas, A. S. (2019). Pengembangan Modul Matematika Berbasis Pakem Pada Materi Bilangan Pecahan Di Sd. TERAMPIL: Jurnal Pendidikan dan Pembelajaran Dasar, 6(1), 49-63.

Kristanto, Yosep Dwi. (2016). Modul Pecaban. Yogyakarta.

Kurniati, A. (2016). Pengembangan modul matematika berbasis kontekstual terintegrasi ilmu keislaman. Al-Khwarizmi: Jurnal Pendidikan Matematika dan Ilmu Pengetahuan Alam, 4(1), 43-58.

Kurniawati, L. D. (2019). Penerapan Model Number Head Together untuk Meningkatkan Prestasi Belajar IPA Dipandang dari Motivasi Siswa Sekolah Dasar. In Prosiding Seminar Nasional PGSD (pp. 191-199).

Lasmiyati, L., \& Harta, I. (2014). Pengembangan Modul Pembelajaran untuk Meningkatkan Pemahaman Konsep dan Minat SMP. Pythagoras: Jurnal Pendidikan Matematika, 9(2), 161-174.

Mawardi, M. (2014). Model Desain Pembelajaran Kosep Dasar PKn Berbasis Belajar Mandiri Menggunakan Moodle. Kab. Semarang: Widya Sari Press.

Nasution, A. (2018). Pengembangan modul matematika berbasis masalah untuk meningkatkan 
kemampuan pemecahan masalah matematika siswa.

Novalia, H., \& Noer, S. H. (2019). Pengembangan modul pembelajaran matematika dengan strategi PQ4R untuk meningkatkan kemampuan berpikir kreatif dan kemandirian belajar siswa SMA. JPPM (Jurnal Penelitian dan Pembelajaran Matematika), 12(1), 51-65.

Nurdyansyah, N. (2018). Pengembangan Bahan Ajar Modul Ilmu Pengetahuan Alambagi Siswa Kelas Iv Sekolah Dasar. Universitas Muhammadiyah Sidoarjo.

Rayanto \& Sugiyanti (2020). Penelitian Pengembangan Model Addie Dan R2d2: Teori \& Praktek. Lembaga Academic \& Research Institute.

Soleh, A. (2009). Faktor-faktor yang Mempengaruhi Keberhasilan Siswa Kelas 2 TMO SMK texmaco semarang pada Mata Diklat service engine dan Komponen-komponennya. Jurnal Pendidikan Teknik Mesin, 9(2).

Syahrir, S., \& Susilawati, S. (2015). Pengembangan Modul Pembelajaran Matematika Siswa SMP. Jurnal Ilmiah Mandala Education, 1(2), 162-171.

Tjiptiany, E. N., As'ari, A. R., \& Muksar, M. (2016). Pengembangan modul pembelajaran matematika dengan pendekatan inkuiri untuk membantu siswa SMA kelas X dalam memahami materi peluang. Jurnal Pendidikan: Teori, Penelitian, dan Pengembangan, 1(10), 1938-1942.

Wahyuningtyas, D. T., \& Pratama, E. (2018). Pengembangan Modul Pembelajaran Pecahan Sederhana Kelas III SD dengan Pendekatan Contextual Teaching \& Learning (CTL). JP (Jurnal Pendidikan): Teori dan Praktik, 3(1), 34-37. 